\title{
Malgorzata Porada-Rochoń
}

University of Szczecin

e-mail: malgorzata.rochon@wzieu.pl

\section{Justyna Franc-Dąbrowska}

Warsaw University of Life Sciences - SGGW

e-mail: justyna_franc_dabrowska@sggw.pl

\section{CATEGORIZATION OF INSTRUMENTS USED IN TURNAROUND PROCESSES UNDER CONDITIONS OF FINANCIAL DISTRESS*}

\section{KATEGORYZACJA INSTRUMENTARIUM WYKORZYSTYWANEGO W PROCESACH DOSTOSOWAWCZYCH W WARUNKACH ZABURZEŃ FINANSOWYCH}

DOI: $10.15611 /$ nof.2015.4.07

JEL Classification: G30, G31, G34

Summary: The objective of this article was to analyze and categorize the instruments implemented by enterprises recognized as being financially distressed, used in response to such distress. The instruments were implemented in the turnaround process. In order to achieve the research objective, the following research hypothesis was verified: depending on the size of the enterprise (small or medium), various instruments are assessed as being effective and thus they can be subjected to the categorization process. The study encompassed a total of 259 small and 138 medium-sized enterprises from Poland, the Czech Republic, Slovakia, Hungary, Romania and Ukraine.

Keywords: financial distress, small and medium enterprises, turnaround process.

Streszczenie: Celem artykułu była analiza i kategoryzacja instrumentarium wdrażanego przez przedsiębiorstwa uznane jako zaburzone finansowo, które stosowano w odpowiedzi na kryzys. Instrumentarium wdrażane było w procesie dostosowawczym. Aby zrealizować cel badań, poddano weryfikacji następującą hipotezę badawczą: w zależności od wielkości przedsiębiorstwa (w podziale na małe i średnie) różne instrumenty są oceniane jako

* The project has been financed from the funds of the National Science Centre, awarded on the basis of decision no. DEC-2011/03/B/HS4/05503.

We express thanks to the anonymous reviewer for valuable advice that made it possible to improve this work. 
skuteczne, a tym samym można je poddać procesowi kategoryzacji. Badaniem objęto łącznie 259 małych oraz 138 średnich przedsiębiorstw z Polski, Czech, Słowacji, Węgier, Rumunii oraz Ukrainy.

Słowa kluczowe: zaburzenia finansowe, małe i średnie przedsiębiorstwa, proces dostosowawczy.

\section{Introduction}

Financial distress, with its early effects identifiable in late 2007 and early 2008, the multidimensional changes in the environment, as well as the hardly predictable scenarios in the field of the economy and financial markets and the associated complex processes, have led to increased uncertainty and risk at the level of macro and micro-enterprises. The events of recent years have amplified the emergence of unprecedented financial distress on the macro scale, which is a component - or at least a contributing factor - of financial crises.

According to research, financial distress on the market is destructive to the financial condition of companies. The worsening of the financial condition is even more visible in those companies which have been recognized as experiencing financial distress [Campbell, Hilschera, Szilagyia 2008; Geroski, Gregg 1996; Kaplan, Stein 1993; Ozkan, Ozkan 2004; Porada-Rochoń 2013]. Taking into account the fact that financial distress on the micro scale is a "stage in the complex and dynamic process of the worsening of the financial condition, being a result of the impact of a significant external determinant, it requires the company to make an informed choice of the configuration of financial decisions in the turnaround process" [Porada-Rochon 2013, p. 60]. The selection of the appropriate instrument in the turnaround process is of key significance due to its final result: survival or bankruptcy. This is all the more difficult, as has been pointed out by Jahur and Quadir [2012], due to the fact that there are many reasons for financial distress, as well as many different symptoms which are often mutually exclusive.

In the literature on the subject, there are many examples of turnaround processes [O’Neill 1986a; O’Neil 1986b; Suszyński 1999; Slatter, Lovett 2001; Pretorius 2009; Faulhaber, Landwehr 2011]. Many authors point to the necessity of permanent adaptation to the existing conditions. The high level of diversification of turnaround process models is due to the primary objective of the managers, that is, survival and/ or development. Due to the above, substantial diversification is observed with regard to the role and division of instruments in the turnaround process. Thus, there is a visible need for the assessment of the effectiveness of the instruments employed by companies classified as undergoing financial distress. 


\section{Research methodology}

In the categorization process, the instruments used in turnaround processes can be divided as follows :

1. Instruments effective in the turnaround process.

2. Instruments characterized by a medium level of effectiveness.

3. Instruments characterized by a low level of effectiveness.

The perceived instrument effectiveness level of individual groups of instruments was determined using a five-point Likert scale, and effective companies were considered to be those with a weight above 3 assigned by entrepreneurs, those belonging to the medium effectiveness category fell within the range of $2.0-2.99$, while those of low effectiveness - below 1.99 (inclusively).

During the subsequent stage of categorization, the internal management system instruments were identified in each group (those focused on processes taking place within the company), as well as the external management system instruments (focused on processes taking place outside the company). This division is the conventional one, since every tool and action exerts a different impact on the enterprise and on its environment. The concept of division into "internal" and "external" instruments was to show that some of them are not entirely dependent on the management of the enterprise, and its financial condition may be influenced by external factors, sometimes emerging unexpectedly as a surprise to the decisionmakers. Thus, it is not equally easy to determine the effects of application of various instruments at the stage of their use.

The study was conducted for a total of 259 small and 138 medium-sized enterprises from Poland, the Czech Republic, Slovakia, Hungary, Romania and Ukraine using a questionnaire. The enterprises were classified as undergoing financial distress. The objective at this stage of research was to categorize the instruments implemented by the financially distressed enterprises in response to such distress. The instruments were used in the turnaround process. In order to achieve the objective, the following hypothesis was verified: depending on the size of the enterprise (small or medium), various instruments are assessed as being effective, and thus they can be subjected to the categorization process.

In their further research, the authors are considering the possibility of proposing a more detailed categorization taking into account the enterprise development phase, which strongly determines the instruments used in the turnaround processes. This, however, requires a much broader analysis of the instruments analyzed, and, due to the limited scope of this study, the approach will be discussed more thoroughly in subsequent articles. 


\section{The research results}

It was found that according to the opinions of the surveyed entrepreneurs the diversification of levels of effectiveness was substantial, depending both on the type of instrument applied and on whether the instruments were applied to turnaround processes in a small or medium-sized enterprise. The highest level of instrument's effectiveness include the reduction of bonuses and reduction of administrative expenses was observed both in small and in medium-sized enterprises. On the other hand, some instruments of low level of effectiveness were also identified - these include takeovers, mergers or the sale of corporate units. The low level of effectiveness of these instruments may - at least partially - be caused by the fact that the study was focused on the sector of small and medium-sized enterprises, and in this group of entities, takeovers, mergers and the sale of a part of enterprises - due to their scale - is a less often encountered phenomenon. This does not mean, however, that instruments of this type are not used in the turnaround process of this group of enterprises.

Table 1. Instruments rated as the highest level of effectiveness in the turnaround process in the small enterprises examined (averaged according to the 5-point Likert scale)

\begin{tabular}{|l|c|}
\hline \multicolumn{1}{|c|}{ Instrument } & Level of effectiveness \\
\hline \multicolumn{2}{|c|}{ Instruments of the internal management system } \\
\hline Personnel lay offs & 4.01 \\
\hline Reducing bonuses & 3.73 \\
\hline Reduction of administrative expenses & 3.23 \\
\hline \multicolumn{2}{|c|}{ Instruments of the external management system } \\
\hline \multicolumn{2}{|c|}{ None } \\
\hline
\end{tabular}

Source: own compilation.

In order to refine the analysis further, in Table 1 we present the instruments which represent the highest level of effectiveness in turnaround processes dedicated to small enterprises. These instruments would be included in the internal management system, that is the reduction of bonuses and administrative expenses. Unquestionably, these are the groups of instruments which - in most cases - are implemented in the preliminary phase of the turnaround process in order to limit the outflow of money. These instruments represent a level of effectiveness over the short-term perspective (their positive effect is "visible" at once). Instruments evaluated as effective in medium-sized enterprises were also assessed further and their specification can be found in Table 2.

Data presented in Table 3 indicates that in medium-sized enterprises, the highest level of effectiveness in the turnaround process are the same instruments as in the 
Table 2. Instruments rated as the highest level of effectiveness in the turnaround process in the medium-sized enterprises examined (averaged according to the 5-point Likert scale)

\begin{tabular}{|c|c|}
\hline Instrument & Level of effectiveness \\
\hline \multicolumn{2}{|c|}{ Instruments of the internal management system } \\
\hline Personnel lay offs & 3.80 \\
\hline Reducing bonuses & 3.48 \\
\hline Reduction of administrative expenses & 3.01 \\
\hline \multicolumn{2}{|c|}{ Instruments of the external management system } \\
\hline & \\
\hline
\end{tabular}

Source: own compilation.

small enterprises, probably due to the same reason, which is the quick financial effect that can be achieved over a short period of time. In the later stage of research, instruments of medium effectiveness were identified and presented for small enterprises in Table 3 and for medium-sized ones in Table 4.

According to the analyses, the instruments of medium level of effectiveness in the turnaround process constitute the most numerous group, both for small and for medium-sized enterprises. The highest level of effectiveness of instruments in this group include the restructuring of units (e.g. establishment of cost centers and profit centers), as well as the reduction of the price of purchase of raw materials and the negotiating of more favorable payment conditions. On the other hand, the lowest level of effectiveness in this group was increasing effectiveness which, due to the market conditions, should be considered a justified opinion and the corresponding expansion to new business segments. Thus, regardless of whether we consider instruments applicable to the internal or the external processes of an enterprise, which exert an impact on its financial condition, declarations with regard to their level of effectiveness made by entrepreneurs, remain consistent.

Somewhat different observations were made with regard to enterprises characterized by a medium scale of operation, in which the instruments with the highest level of effectiveness (in the group of those characterized by medium level of effectiveness) included the reduction of investment in research and development, the implementation of a system that supports management and the negotiation of more favorable payment conditions (the same instrument appeared on the list compiled for small enterprises). Instruments with a lower level of effectiveness in this group included the negotiation of favorable conditions of lease (rental), the improvement of knowledge concerning customer behavior, the replacement of suppliers and outsourcing. Despite certain differences in the perception of the 
Table 3. Instruments rated as medium level of effectiveness in the turnaround process in the small enterprises examined (averaged according to the 5-point Likert scale)

\begin{tabular}{|c|c|}
\hline Instrument & Level of effectiveness \\
\hline \multicolumn{2}{|c|}{ Instruments of the internal management system } \\
\hline Restructuring organizational units & 2.91 \\
\hline Reducing purchasing prices & 2.90 \\
\hline Expenditure cuts on a wide range of $\mathrm{R} \& \mathrm{D}$ & 2.83 \\
\hline Reduction of marketing and selling costs & 2.70 \\
\hline Implementation of the systems that are supportive to management & 2.59 \\
\hline Salary reduction & 2.43 \\
\hline Reevaluating profitability of product/services & 2.41 \\
\hline Closing unprofitable areas of the business & 2.28 \\
\hline Divestitures & 2.27 \\
\hline Deferring capital or major investments & 2.23 \\
\hline Changing the supervision and monitoring system & 2.14 \\
\hline Diversification of services & 2.11 \\
\hline Becoming more operationally efficient/streamlining operations & 2.05 \\
\hline \multicolumn{2}{|c|}{ Instruments of the external management system } \\
\hline Better use of financial terms with vendor/suppliers & 2.93 \\
\hline Negotiating better terms with landlords/property owners & 2.59 \\
\hline Changing distributors & 2.40 \\
\hline Reallocating distributors & 2.40 \\
\hline Reevaluating profitability of customer segments & 2.37 \\
\hline Improved knowledge of consumer behavior & 2.31 \\
\hline Outsourcing & 2.23 \\
\hline Consolidating supplier portfolio & 2.20 \\
\hline Expanding into new business segments & 2.13 \\
\hline
\end{tabular}

Source: own compilation.

instruments with a higher and lower level of effectiveness (within the group of instruments characterized by medium level effectiveness), depending on the size of the enterprise it can be noted that the higher level of effectiveness is ascribed mainly to those instruments which generate effects visible over a short period of time, and at a very general level they can be classified as cost-based instruments (or, referring to financial flow, as expense-based instruments), which obviously should be regarded as justified from the perspective of the rationality of decision-making.

Tables 5 and 6 present those instruments which have been classified as the least effective ones. Their types are similar in small and in medium-sized enterprises, both in the group of those applicable to the internal decisions of entrepreneurs and those which are related to activity outside the enterprises. 
Table 4. Instruments rated as medium level of effectiveness in the turnaround process in the medium-sized enterprises examined (averaged according to the 5-point Likert scale)

\begin{tabular}{|c|c|}
\hline Instrument & Level of effectiveness \\
\hline \multicolumn{2}{|c|}{ Instruments of the internal management system } \\
\hline Implementation of the systems that are supportive to management & 2.73 \\
\hline Expenditure cuts on a wide range of $R \& D$ & 2.71 \\
\hline Restructuring organizational units & 2.61 \\
\hline Reducing purchasing prices & 2.29 \\
\hline Closing unprofitable areas of the business & 2.28 \\
\hline Reduction of marketing and selling costs & 2.23 \\
\hline Reevaluating profitability of product/services & 2.17 \\
\hline Divestitures & 2.15 \\
\hline \multicolumn{2}{|c|}{ Instruments of the external management system } \\
\hline Better use of financial terms with vendor/suppliers & 2.67 \\
\hline Consolidating supplier portfolio & 2.26 \\
\hline Reevaluating profitability of customer segments & 2.21 \\
\hline Reallocating distributors & 2.11 \\
\hline Outsourcing & 2.08 \\
\hline Changing distributors & 2.03 \\
\hline Negotiating better terms with landlords/property owners & 2.00 \\
\hline Improved knowledge of consumer behavior & 2.00 \\
\hline
\end{tabular}

Source: own compilation.

Table 5. Instruments rated as the lowest level of effectiveness in the turnaround process in the small enterprises examined (averaged according to the 5-point Likert scale)

\begin{tabular}{|c|c|}
\hline Instrument & Level of effectiveness \\
\hline \multicolumn{2}{|c|}{ Instruments of the internal management system } \\
\hline Selling entries business units & 1.31 \\
\hline \multicolumn{2}{|c|}{ Instruments of the external management system } \\
\hline Involvement of main stakeholders & 1.96 \\
\hline Expanding into new market & 1.82 \\
\hline Mergers & 1.45 \\
\hline Acquiring (parts of) companies & 1.13 \\
\hline
\end{tabular}

Source: own compilation.

The instruments rated at the lowest level of effectiveness include takeover, sale of corporate units and expansion into new markets. To a certain extent we may consider the fact that a reduction of salaries has been assessed as being of a slight effectiveness in the turnaround process (in medium-sized enterprises) as surprising. In our opinion, this may be the result of the process of the limitation of the increase 
Table 6. Instruments rated as the lowest level of effectiveness in the turnaround process in the medium-sized enterprises examined (averaged according to the 5-point Likert scale)

\begin{tabular}{|l|c|}
\hline \multicolumn{1}{|c|}{ Instrument } & Level of effectiveness \\
\hline \multicolumn{2}{|c|}{ Instruments of the internal management system } \\
\hline Salary reduction & 1.98 \\
\hline Closing unprofitable areas of the business & 1.85 \\
\hline Deferring capital or major investments & 1.78 \\
\hline Changing the supervision and monitoring system & 1.76 \\
\hline Diversification of services & 1.66 \\
\hline Becoming more operationally efficient/streamlining operations & 1.40 \\
\hline Selling entries business units & 1.17 \\
\hline \multicolumn{2}{|c|}{ Instruments of the external management system } \\
\hline Involvement of main stakeholders & 1.97 \\
\hline Mergers & 1.77 \\
\hline Expanding into new business segments & 1.61 \\
\hline Acquiring (parts of) companies & 1.31 \\
\hline Expanding into new market & 1.28 \\
\hline
\end{tabular}

Source: own compilation.

of salaries in the crisis years which has established them at a relatively low level, where their further (real) reduction may become a strong demotivator. As a result, while limiting the costs immediately, the reduction of salaries could lead to employee rotation and/or reducing the effectiveness of work due to a sense of disappointment. The remaining instruments which have been identified as being at the lowest level of effectiveness are tools which require long-term implementation, and thus their effectiveness is more uncertain.

\section{Conclusions}

Analysis of the effectiveness of the instruments implemented in the turnaround process under conditions of financial distress indicate the following:

- Diversity in the assessment of the instruments' effectiveness level being implemented in small and medium-sized enterprises. On average, a slightly higher level of effectiveness has been defined for small enterprises. This may be due to the fact that small enterprises use more instruments which are often complementary, therefore their level of effectiveness may be perceived as being higher.

- The most significant differences are visible in terms of the number of instruments (tools and actions) regarded as being of a low level of effectiveness. A much broader range of instruments has been recognized as having a lower level of effectiveness in the case of medium-sized enterprises. This points to the attempts to improve the financial situation of enterprises using different methods. This should be seen as a positive phenomenon. 
- Differentiation of the instruments used by entrepreneurs allows for a clear categorization of the instruments used to improve the financial condition of enterprises. Such tools are used in the process of improving the financial situation of enterprises which are the result of decisions made within the enterprise (and relate to the business transactions in companies). They are therefore financial management tools that indicate the active attitude of entrepreneurs. The second group are instruments which affect the situation of companies concerning the economic environment. In this group it was found similar but not identical, depending on the level of effectiveness in small and medium-sized enterprises.

- In general, the average level of effectiveness both in small and in medium-sized enterprises, was assigned to instruments belonging to the cost reduction plan which, in turn, can be associated with the rapidity of the effects for individual instruments. Undoubtedly, the quickest effect can be observed in the case of those instruments which exert a direct impact on the level of costs (or expenses) in enterprises.

- Summing up, the instruments used in turnaround processes under conditions of financial distress in small and medium-sized enterprises require categorization due to the diversified level of their effectiveness, as well as the extent of the decisions and the pace of impact (perceived directly by entrepreneurs), and the categories proposed should be treated as the starting point for further in-depth research.

\section{References}

Campbell J.Y., Hilscher J., Szilagyi J., 2008, In search of distress risk, The Journal of Finance, Vol. LXIII, No. 6.

Faulhaber P., Landwehr N., 2011, Turnaround management w praktyce. Jak wykorzystać kryzys w przedsiębiorstwie, by odrodziło się na nowo, CeDeWu, Warszawa.

Geroski P.A., Gregg P., 1996, What makes firms vulnerable to recessionary pressures?, European Economic Review, Vol. 40, Iss. 3-5.

Jahur S.M., Quardir N.M., 2012, Financial Distress in Small and Medium Enterprises of Bangladesh: Determinants and Remedial Measure, Economic Management, Vol. 15, No. 1.

Kaplan S.N., Stein S.T., 1993, The evolution of buyout pricing and pricing and financial structure, Quarterly Journal of Economics, Vol. CVIII, Iss. 2.

O'Neill, H., 1986a, An analysis of the turnaround strategy in commercial banking, Journal of Management Studies, Vol. 23.

O'Neill, H., 1986b, Turnaround and recovery: What strategy do you need?, Long Range Planning, Vol. 19.

Ozkan A., Ozkan N., 2004, Corporate cash holdings: An empirical investigation of UK companies, Journal of Banking and Finance, Vol. 28, No. 9.

Porada-Rochoń M., 2013, Modele decyzji finansowych MŚP w wybranych krajach Europy Środkowo-Wschodniej w warunkach zaburzeń finansowych, Polskie Towarzystwo Ekonomiczne, Szczecin, p. 60 .

Pretorius M., 2009, Defining business decline, failure and turnaround: A content analysis, SAJESBM NS, Vol. 1, Iss. 1.

Slatter S., Lovett D., 2001, Restrukturyzacja firmy, WIG-Press, Warszawa.

Suszyński C.,1999, Restrukturyzacja przedsiębiorstw. Proces zarządzania zmianami, PWE, Warszawa. 